\title{
Diversity and Distribution of Syrphid Fly Communities in Temperate Fruit Orchard of Kashmir, India
}

\author{
Akhtar Ali Khan* and Shazia Riyaz \\ Division of Entomology, Sher-e-Kashmir University of Agricultural sciences and \\ Technology of Kashmir, Shalimar, Srinagar-190025, Jammu and Kashmir, India \\ *Corresponding author
}

\begin{tabular}{|c|c|}
\hline & A B S T R A T \\
\hline Keywords & \multirow{4}{*}{$\begin{array}{l}\text { The studies on the biodiversity of aphidophagous syrphid flies were made in } \\
\text { temperate fruit ecosystem including apple, pear, peach and plum orchards of } \\
\text { Kashmir during } 2013 \text { and } 2014 \text {. Nineteen species of syrphid flies belongs to } 2 \\
\text { sub families, } 4 \text { tribes and } 12 \text { genera were identified from fruit orchards of } \\
\text { Kashmir. Among these, Eristalis tenax followed by Eoseristalis cerealis } \\
\text { Eristalis interruptus and Episyrphus balteatus were pre-dominant species of } \\
\text { syrphid flies in fruit orchards of Kashmir. Among all orchards, the highes } \\
\text { distribution and relative abundance of syrphid flies were recorded in apple } \\
\text { orchard followed by pear orchard and lowest in peach orchard. Species } \\
\text { diversity of aphidophagous syrphid flies were recorded greater in fruit orchard } \\
\text { of Harwan of district of Srinagar and Species richness of aphidophagous } \\
\text { syrphid flies were recorded greater in fruit orchard of Warpora of district of } \\
\text { Baramullah of Kashmir. }\end{array}$} \\
\hline $\begin{array}{l}\text { Diversity, } \\
\text { Distribution, } \\
\text { Species diversity, } \\
\text { Species richness, } \\
\text { Syrphid fly, } \\
\text { Temperate Fruit } \\
\text { orchard. }\end{array}$ & \\
\hline Artic & \\
\hline $\begin{array}{l}\text { Accepted: } \\
\text { 29 June } 2017 \\
\text { Available Online: } \\
10 \text { July } 2017\end{array}$ & \\
\hline
\end{tabular}

\section{Introduction}

Syrphids (Diptera: Syrphidae) are one of the most important predators of aphids and are known to regulate the prey population effectively (Ssymank et al., 2008). They are commonly known as hoverflies, flower flies or sunflies owing to their peculiar behaviour of hovering in sun over the flowers to feed on pollen and nectar (Kevan, 2002). The family syrphidae includes nearly 6000 species worldwide (Pape and Evenhuis, 2013; Miranda et al., 2013). In India, predatory syrphidae is represented by 312 species (Ghorpade, 1981) and from western Himalaya; India recoded 169 species of syrphid flies (Shah et al., 2014). Among the predators of aphids, more important ones are the ladybird beetle (Coleoptera: Coccinellidae) and hoverflies (Diptera: Syrphidae). Although a considerable amount of research has been conducted on the Biodiversity, biology, preying potential and ecology of the coccinellids and Chrysoperla (Khan et al., 2007; Khan and Mir 2008; Khan, 2009; Khan et al., 2009; Khan, 2010; Mushtaq and Khan, 2010a, b; Shah and Khan, 2013, 2014); the syrphids, as a group have been somewhat neglected (Ghorpade, 1981). However, the management of syrphidae in 
biological and integrated control is not an easy task because of their relatively high ecological demands in the environment (Mengual and Thompson 2011). Among the important predators of aphid, syrphids play a dominant role next to coccinellids (Khan et al., 2016). However, not much attention has been paid to make studies on syrphids in agro ecosystem (Hopper et al., 2011).

The identification and knowledge of hoverflies has helped to farmer about their predatory role, as pollinator, harmless to plants/crops and despite their mimicry of the black and yellow stripes of wasps, which serves to ward off predators (Haenke et al., 2009). Farmer was suggested for better and safe utilization of insecticides against predatory syrphids in sustainable manner in horticulture of Kashmir (Abrol, 1993). There was need in today's context to reduce pesticide usage on the world's crop and optimize natural bio-control (Hopper et al., 2011). Hence, the question of information pertaining to biodiversity and successful utilization of syrphid flies in today's context of pest management is not yet explored due to sole reliance on chemical control. It seems that we are for away in taking the advantages of the nature. Keeping in view that above fact, an endeavour would be to go a step ahead in respect to exploring distribution and diversity of aphidophagous syrphid fly in fruit orchard of Kashmir to support the sustainable pest management.

\section{Materials and Methods}

The studies on the biodiversity of aphidophagous syrphid were made in fruit orchard including the main fruit crops of these states are apple, pear, peach and plum during 2013 and 2014. The observations were recorded weekly in different crops from Srinagar and Baramulla District of Kashmir. Three locations viz., Shalimar, Harwan and
Gulab Bagh of district Srinagar and Wagoora, Mamoosa, Warpora of district Baramulla were selected for the sampling of syrphid flies of fruit orchard of Kashmir from April to September during 2013 and 2014.

\section{Method of sampling}

Two sampling methods were used, the detail as follows:

\section{Sweep net}

In sweep net method, adult syrphids were collected by making double stroke sweeps by insect collection net (Diameter $32 \mathrm{~cm}$ and handle $92 \mathrm{~cm}$ ). Each stroke of sweep-net will a complete oscillation and was repeated five times randomly from five different places of field.

\section{Hand picking}

The maggots (larvae) population was recorded on the basis of population per plant. The maggots were collected into plastic tube by hand picking method.

\section{Preservation and identification}

The collected samples were identified upto the species level with the help of literature and confirm by experts. The larvae were reared up to adult stage in separate labelled rearing cages by providing fresh aphids every day. After adult emergence, the adults were preserved dry and grouped into different categories based on morphological features and counted.

\section{Statistical analysis}

\section{Relative abundance}

The relative abundance was calculated by using the formula: 
$\mathrm{R}=\mathrm{ni} / \mathrm{N} * 100$

Where, $\mathrm{R}$ is the relative abundance (\%), "ni" is the number of individual of the ith species and " $\mathrm{N}$ " is the total number of specimens.

\section{Ecological indices for quantitative analysis}

Quantitative estimation of individual species was made using the data derived from field survey. Species richness (Da) was calculated using Margalef's richness index and species diversity was calculated by using ShannonWiener diversity index by using the data.

\section{Margalef's richness index}

The simplest measure of species diversity is the number of species or species richness and was calculated after Margalef's (1968).

$\mathrm{Da}=(\mathrm{S}-1) / \log$ e $\mathrm{N}$

Where, $\mathrm{Da}=$ Margalef's richness index, $\mathrm{S}=$ Number of species, and $\mathrm{N}=$ total number of individuals.

\section{Shannon-Wiener diversity index}

The Shannon Wiener diversity index (Shannon, 1948) is calculated by taking the number of each species, the proportion each species is of the total number of individual, and sums the proportion times the natural log of the proportion for each species. Since this is a negative number, we then take the negative of the negative of this sum. The higher the number, the higher is the species diversity. In the ideal situation, one should compare population that is the same size in numbers of individuals.

$\mathrm{H}=-\sum \mathrm{pi} \ln \mathrm{pi}$

Where, $\mathrm{H}=$ Shannon-Wiener diversity index $\mathrm{Pi}=$ the observed proportion of a particular species.
The value of $\mathrm{H}$ near zero would indicate that every species in the sample is the same. A value near 4.6 would indicate that the numbers of individuals are evenly distributed between all the species. Values in the middle are ambiguous which an obvious flaw of this index is and, thus, care is taken when using this index. All statistical analyses were performed by using the R-software (R Development Core Team, 2015).

\section{Results and Discussion}

The important report from this study is that annual changes in the syrphid complex are considerable, both qualitatively and quantitatively (Hagvar and Nielson, 2007). This is important which ecological studies on syrphid fauna are carried out for one season only. A reason why certain species dominating one year are absent other years can be weather conditions, food, and density dependent factors may also influence the annual variation (Gilbert, 2005). In present study a total of 2844 individuals of 19 species belong to 13 genera from 4 tribes and two sub families of hoverflies were recorded in fruit orchards of Kashmir in the study period during 2013 and 2014. The details of distribution, relative abundance, species diversity and species richness of aphidophagous syrphid flies were recorded in apple, pear, plum and peach orchards of 6 locations and two districts of Kashmir are as under:

\section{Distribution of syrphid flies}

In fruit ecosystem, 19 species of syrphid flies were recorded during 2013. Out of 19 species, $15,12,7$, and 9 species were recorded in apple, pear, plum and peach ecosystem of Shalimar; 16, 13, 8 and 7 species of syrphid fly were recorded in apple, pear, plum and peach ecosystems of Harwan; 14, 3, 9 and 8 species were recorded in apple, pear, plum 
and peach ecosystem of Gulabagh of Srinagar district during 2013 (Table 1). In district Baramullah;15, 14, 9 and 8 species were recorded in apple, pear plum and peach ecosystem of Wagoora; 14, 10, 6 and 5 species from apple, pear, plum and peach ecosystem of Mamoosa; 17, 10, 9 and 9 species were recorded in apple, pear, plum and peach ecosystem of Warpora, respectively during 2013. Among all species, Eristalis tenax was the most distributed species followed by Eoseristalis cerealis and Episyrphus balteatus were recorded during 2013 in fruit ecosystem. Species of subfamily Eristalinae were more distributed in fruit ecosystem as compared to sub-family Syrphidae; only two species viz., Episyrphus balteatus and Sphaerophoria scripta were evenly distributed in fruit ecosystem during 2013.

In 2014, 18 species of syrphid flies were recorded. Syritta sp was least distributed species in fruit ecosystem during 2013 and was not recorded during 2014 in fruit ecosystem (Table 2). Out of 18 species, 17, 15, 9 and 8 species were recorded from apple, pear, plum and peach ecosystems of Shalimar; $15,12,12$ and 7 species were recorded in Harwan of same fruit ecosystem, respectively. In Gulabagh, 16 species from apple, 13 species from pear and plum and 9 species from peach ecosystem of Srinagar district were recorded during 2014. In Baramullah district, 17, 10. 9 and 10 species were recorded from apple, pear, plum and peach ecosystems of wagoora; 16, 14, 11 and 11 species from Mamoosa and 14, 12, 9 and 7 species from warpora location in apple, pear, plum and peach ecosystem, respectively during 2014. Among all species, Eristalis tenax followed by Eoseristalis cerealis, Eristalis interruptus and Episyrphus balteatus were more evenly disrtbuted during 2014. The sub- family- Eristalinae included maximum population as compared to sub-familySyrphidae; Copestylum sp. and Syrphus sp. were least distributed species of syrphid fly in fruit ecosystem during 2014. Species belonging to the subfamily Eristalinae (2285 individuals) are most distributed species in all locations and orchards of Kashmir (Similar to the result found by Frank, 1999). Most of aphid species in the study habitats appeared in May and June, suggesting that larval diet is also very important in determining population dynamics of aphidophagous species (Naderloo and Rad, 2014). The result indicated that in the study areas, the most distributed species are E. tenax (L) followed by E. cerealis (Fabicius) and E. interupus (Harris) of subfamily Eristalinae. In sub family Syrphinae, E. balteatus and S. scripta are the most distributed species in all orchards and locations of Kashmir. These species have adopted and distributed to a wide range of geographic area and cropping pattern, therefore, they can be consider as the most successful hoverflies species (Speight, 2008; Naderloo and Rad, 2014). Among four orchards, most of syrphidflies were recorded in apple orchard in both the year followed by pear orchard and with the concern of location the most distributed location was Wagoora followed by Shalimar.

\section{Relative abundance of syrphid flies}

Among all 19 species, highest mean population of E.tenax (14.69\%) followed by E.interruptus (11.84\%), E.lineata (9.77\%), E. aeneus $(9.63 \%)$ and Episyrphus balteatus $(9.20 \%)$ were recorded in fruit orchard of Kashmir during 2013. Least population $(0.99 \%)$ of Copyestylum sp. followed by syritta sp (1.71\%) and Syrphus sp. (1.78\%) were recorded in fruit ecosystem during 2013. The population of E.tenax was recorded highest in almost all fruit crops including Apple, Pear, Plum and peach in different location of district Shalimar and Baramullah and Gulabagh location of district Srinagar, the E. tenax was not observed in peach orchard. 
In some crops the other abundant species, E.interruptus was not observed viz., peach crop in Gulabagh location of district Srinagar, plum and peach crop of Mamoosa and peach crop of location Warpora of district Baramullah during, 2013. Among all fruit crops, the syrphid flies were observed highest in apple orchards followed by pear orchard.

Out of two sub-families, the abundance of Eristalinae $(72.7 \%)$ was higher than the syrphidae $(27.3 \%)$ in all locations, orchards and districts during 2013 (Table 3). In subfamily Eristalinae, the most abundant species was E. tenax $(14.7 \%)$ followed by Eoseristalis cerealis (11.8\%) and under the sub-family: Syrphinae; Episyrphus balteatus $(9.2 \%)$ followed by Sphaerophoria scripta $(6.7 \%$ )were recorded in fruit orchards during 2013. Among sub-family: Eristalinae; Copestylum sp. followed Syritta $s p$ were found least abundant while as in sub-family syrhinae, the least abundant species was syrphus sp. followed by Eupeodus corolla during 2013 (Table 3). With the concern of different fruit orchard, least abundance of syrphid species and their number was recorded in peach orchard while as highest abundant and higher species was recorded in apple orchard during 2013.

In 2014, the highest abundance specie was also E. tenax (12.3\%) followed by E.interruptus (10.5\%), Eoseristalis cerealis (9.7\%) and Episyrphus balteatus (8.6\%) in fruit orchard of Kashmir. Out of two subfamilies, the abundance of Eristalinae (72.8 $\%)$ was higher than the syrphidae $(27.2 \%)$ in all locations, orchards and districts during 2014. In second year, Syritta sp. was not recorded and least abundant species of syrphid fly was Helophilus sp (2.2\%) followed by Copestylum sp. (2.4\%) in sub family- Eristalinae and Eupeodus corolla (2.9\%) followed by Scaeva pyrastri $(3.12 \%)$ during 2014. Out of total 18 species, most of the species of syrphid fly was recorded in apple orchard of all location ans least species was recorded in peach ecosystem during 2014, which was quite similar to 2013. The composition of different species of sub-family -Eistalinae was ranged between 53.2\% (plun orchards in Mamoosa) to $83.33 \%$ (plum orchard in Gulabagh) as compared to subfamily Syrphus which was $16.67 \%$ (plum orchard in Gulabagh) to $46.88 \%$ (plum orchard in Mamoosa) during 2014. In subfamily- Eristalinae, the highest abundant species was Eristalis tenax (12.28\%) followed by E.interruptes (10.52\%) and Eoseristalis cerealis $(9.67 \%)$ while as least abundant species was Palpada sp. (2.17\%) followed by Helophilus sp. (2.25\%).

In subfamily- syrphidae, the highest abundant species was Episyrphus balteatus (8.56\%) followed by Sphaerophora scripta (6.46\%) and Sphaerophora bengalensis (3.31\%) during 2014 (Table 4). Among the predatory Syrphidae, the Eristalis tenax (13.5\%) was found most abundant syrphid species followed by Eoseristalis cerealis (10.7\%), E.interruptus $(10.1 \%)$ and Episyrphus balteatus (8.9 \%) 2012 to 2013(Figure 1), while as Syritta $s p$. followed by Helophilus $s p$. and Syrphus sp. were recorded as least abundant during 2013 and Palpada sp. followed by Copestylum sp. during 2014. In last year, Syritta sp. was not recorded in fruit ecosystem. Most of the species were recorded abundant in apple orchard followed by pear orchard during both the years. Similar observation was recorded by Trzeinski and Piekarsha-Boniecka (2013) and reported that the apple orchard had a higher abundance of aphids attracting syrphid flies.

\section{Species diversity and richness of syrphid flies}

The parameter of abundance of syrphid flies in fruit ecosystem during 2013 and 2014 was shown in table 5 . 


\section{Int.J.Curr.Microbiol.App.Sci (2017) 6(7): 2794-2805}

Table.1 Distribution of Syrphid flies in fruit orchards of Kashmir during 2013

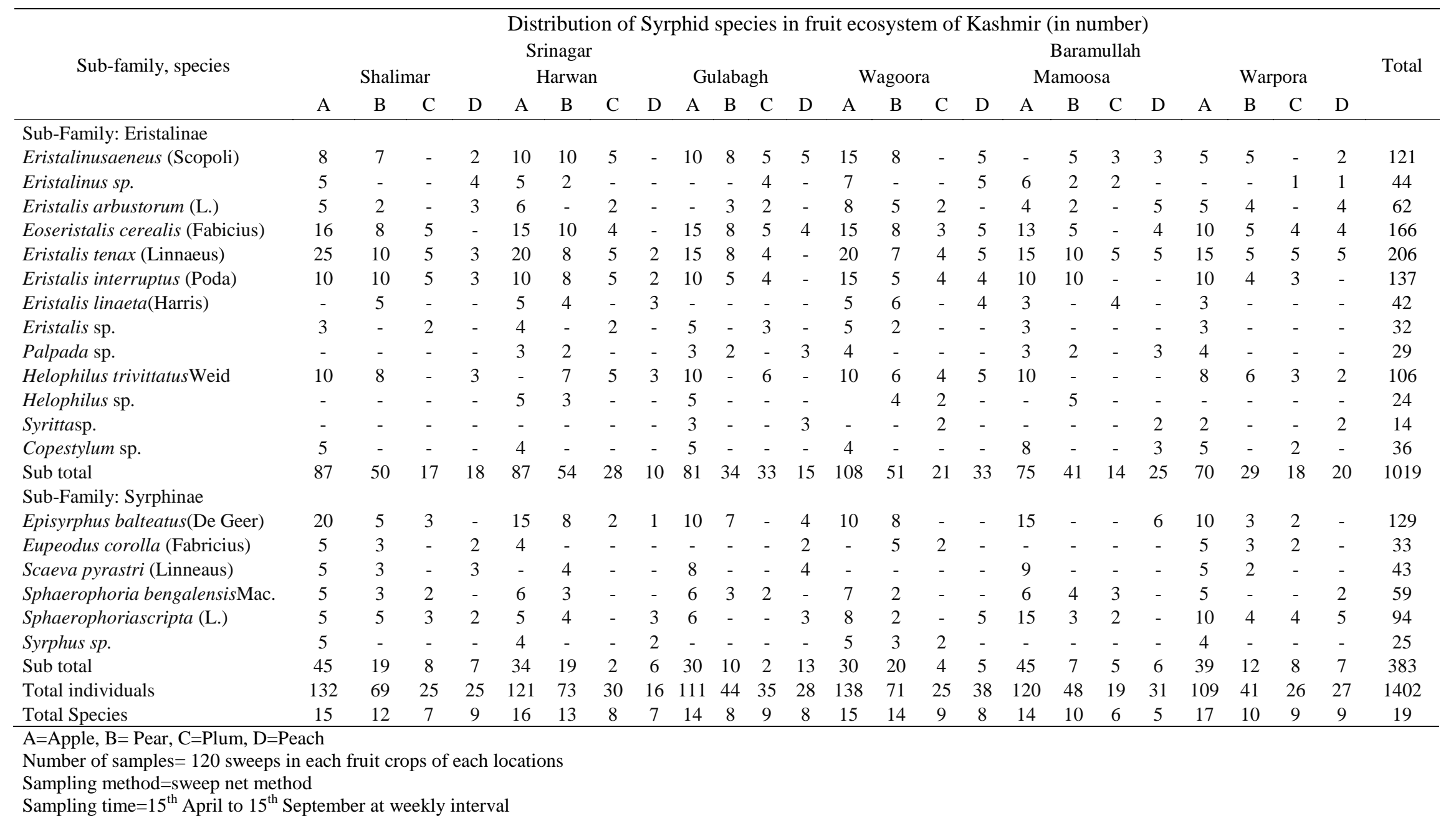




\section{Int.J.Curr.Microbiol.App.Sci (2017) 6(7): 2794-2805}

Table.2 Distribution of Syrphid flies in fruit orchards of Kashmir during 2014

\begin{tabular}{|c|c|c|c|c|c|c|c|c|c|c|c|c|c|c|c|c|c|c|c|c|c|c|c|c|c|}
\hline \multirow{4}{*}{ Sub-family, species } & \multicolumn{24}{|c|}{ Distribution of Syrphid fly species in fruit ecosystem of Kashmir (in number) } & \multirow{4}{*}{ Total } \\
\hline & \multirow{2}{*}{\multicolumn{4}{|c|}{ Shalimar }} & \multirow{2}{*}{\multicolumn{4}{|c|}{$\begin{array}{l}\text { Srinagar } \\
\text { Harwan }\end{array}$}} & \multirow{2}{*}{\multicolumn{4}{|c|}{ Gulabagh }} & \multirow{2}{*}{\multicolumn{4}{|c|}{ Wagoora }} & \multirow{2}{*}{\multicolumn{4}{|c|}{$\begin{array}{l}\text { Baramullah } \\
\text { Mamoosa }\end{array}$}} & \multirow{2}{*}{\multicolumn{4}{|c|}{ Warpora }} & \\
\hline & & & & & & & & & & & & & & & & & & & & & & & & & \\
\hline & A & $\mathrm{B}$ & $\mathrm{C}$ & $\mathrm{D}$ & A & $\mathrm{B}$ & $\mathrm{C}$ & $\mathrm{D}$ & A & $\mathrm{B}$ & $\mathrm{C}$ & $\mathrm{D}$ & A & $\mathrm{B}$ & $\mathrm{C}$ & $\mathrm{D}$ & A & $\mathrm{B}$ & $\mathrm{C}$ & $\mathrm{D}$ & $\mathrm{A}$ & $\mathrm{B}$ & $\mathrm{C}$ & $\mathrm{D}$ & \\
\hline Sub-Family: Eristalinae & & & & & & & & & & & & & & & & & & & & & & & & & \\
\hline Eristalinus aeneus (Scopoli) & 6 & 5 & - & 3 & 9 & 8 & 4 & 2 & 11 & 7 & 5 & 4 & 11 & 9 & 1 & 3 & - & 5 & 2 & 3 & 4 & 6 & - & 1 & 109 \\
\hline Eristalinus sp. & 7 & 2 & - & - & 5 & 4 & 3 & - & 10 & - & - & 4 & 5 & - & - & 3 & 7 & 3 & 2 & 2 & 4 & - & - & - & 61 \\
\hline $\begin{array}{l}\text { Eristalis } \\
\text { (Linnaeus) }\end{array}$ & 8 & 3 & 2 & - & 5 & 2 & - & - & 4 & 2 & - & - & 10 & 5 & 3 & 4 & 5 & 2 & - & - & 5 & 4 & - & 3 & 67 \\
\hline $\begin{array}{l}\text { Eoseristalis } \quad \text { cerealis } \\
\text { (Fabicius) }\end{array}$ & 18 & 5 & 6 & & 10 & & 4 & & 16 & 12 & 4 & 3 & 15 & 6 & & 6 & 12 & 4 & 5 & 5 & 10 & 4 & 3 & & 148 \\
\hline Eristalis tenax (Linnaeus) & 27 & 13 & 5 & 5 & 16 & 10 & - & - & 13 & 6 & 5 & - & 24 & 9 & 3 & 5 & 14 & 8 & - & - & 12 & 7 & 5 & 4 & 191 \\
\hline Eristalis interruptus (Poda) & 14 & 8 & 5 & 4 & 12 & 6 & 7 & 5 & 15 & 2 & 4 & - & 13 & 7 & 5 & 3 & 10 & 4 & 4 & - & 9 & 4 & - & 3 & 144 \\
\hline Eristalis linaeta (Harris) & 5 & - & 4 & 2 & - & 4 & 3 & 6 & 5 & 7 & 2 & 3 & 8 & 4 & - & - & 5 & - & - & 2 & - & 4 & - & - & 64 \\
\hline Eristalis sp. & 6 & 3 & - & - & 5 & - & 3 & - & 4 & 2 & 2 & - & 5 & - & - & 4 & 4 & 2 & 2 & 3 & - & 3 & 2 & 2 & 52 \\
\hline Palpada sp. & - & 4 & - & - & - & 2 & 3 & - & 4 & 2 & 3 & - & 6 & - & - & - & 3 & & 2 & - & 4 & 2 & - & - & 35 \\
\hline Helophilus trivittatusWeid & 14 & 5 & 3 & 4 & 10 & 5 & 8 & 2 & 8 & - & 6 & 4 & 6 & 2 & 3 & - & 8 & 2 & - & 2 & 6 & 3 & 2 & - & 103 \\
\hline Helophilus sp. & 5 & - & - & - & 7 & 2 & - & 2 & 7 & - & 2 & - & 5 & - & 2 & - & 4 & 2 & - & - & 3 & - & - & - & 41 \\
\hline Copestylum sp. & 7 & 2 & - & - & 4 & - & - & 2 & - & - & 2 & 2 & 5 & - & - & - & 3 & 2 & - & 2 & - & - & 2 & - & 33 \\
\hline Sub Total & 117 & 50 & 25 & 18 & 83 & 43 & 35 & 19 & 97 & 40 & 35 & 20 & 113 & 42 & $\begin{array}{l}1 \\
7\end{array}$ & 28 & 75 & 34 & 17 & 19 & 57 & 37 & 14 & 13 & 1048 \\
\hline $\begin{array}{l}\text { Sub-Family: Syrphinae } \\
\text { Episyrphus balteatus (De } \\
\text { Geer) }\end{array}$ & 22 & 4 & 2 & - & 13 & 5 & - & - & 15 & 5 & 2 & 2 & 10 & - & 6 & - & 16 & 4 & 5 & 2 & 8 & 4 & 5 & 3 & 133 \\
\hline Eupeodus corolla (Fabricius) & 6 & 2 & 2 & - & 4 & - & 4 & - & 5 & 2 & 2 & - & 4 & - & - & 2 & - & - & 3 & 2 & 3 & 2 & - & - & 43 \\
\hline Scaeva pyrastri (Linneaus) & 6 & 3 & - & - & 5 & - & 2 & 2 & - & - & - & - & 8 & 4 & 3 & - & 4 & - & 2 & - & 6 & - & 2 & - & 47 \\
\hline $\begin{array}{l}\text { Sphaerophoria engalensis } \\
\text { Mac. }\end{array}$ & 5 & 4 & - & 2 & - & - & 2 & - & 8 & 4 & 3 & - & 4 & 2 & - & 2 & 5 & 2 & - & - & 4 & - & 3 & - & 50 \\
\hline Sphaerophoria scripta (L.) & 5 & 6 & 4 & 2 & 8 & 4 & 4 & - & 5 & 3 & - & 2 & 6 & 4 & 2 & 3 & 8 & 4 & 2 & 3 & 6 & 4 & - & 2 & 87 \\
\hline Syrphus sp. & 5 & - & - & 2 & 4 & 2 & - & - & 3 & 2 & - & 3 & - & - & - & - & 4 & 2 & 3 & 2 & - & - & 2 & - & 33 \\
\hline Sub total & 49 & 19 & 8 & 6 & 34 & 11 & 12 & 2 & 36 & 16 & 7 & 7 & 32 & 10 & $\begin{array}{l}1 \\
1\end{array}$ & 7 & 37 & 12 & 15 & 9 & 27 & 10 & 12 & 5 & 394 \\
\hline Total & 166 & 69 & 33 & 24 & 117 & 54 & 42 & 21 & 133 & 56 & 42 & 27 & 145 & 52 & $\begin{array}{l}2 \\
8\end{array}$ & 35 & 112 & 46 & 32 & 28 & 84 & 47 & 26 & 18 & 1442 \\
\hline Total Species & 17 & 15 & 9 & 8 & 15 & 12 & 12 & 7 & 16 & 13 & 13 & 9 & 17 & 10 & 9 & 10 & 16 & 14 & 11 & 11 & 14 & 12 & 9 & 7 & 18 \\
\hline
\end{tabular}




\section{Int.J.Curr.Microbiol.App.Sci (2017) 6(7): 2794-2805}

Table.3 Relative abundance of Syrphid flies in fruit orchards of Kashmir during 2013

\begin{tabular}{|c|c|c|c|c|c|c|c|c|c|c|c|c|c|c|c|c|c|c|c|c|c|c|c|c|c|c|c|}
\hline \multirow{4}{*}{ Sub-family, species } & \multicolumn{26}{|c|}{ Abundance of Syrphid flies in fruit ecosystem of Kashmir (\%) } & \multirow{4}{*}{$\begin{array}{l}\text { Total } \\
\text { Mean }\end{array}$} \\
\hline & \multicolumn{14}{|c|}{ Srinagar } & \multicolumn{12}{|c|}{ Baramullah } & \\
\hline & \multicolumn{4}{|c|}{ Shalimar } & \multicolumn{4}{|c|}{ Harwan } & \multicolumn{4}{|c|}{ Gulabagh } & \multirow[t]{2}{*}{ Mean } & \multicolumn{4}{|c|}{ Wagoora } & \multicolumn{4}{|c|}{ Mamoosa } & \multicolumn{4}{|c|}{ Warpora } & \multirow[t]{2}{*}{ Mean } & \\
\hline & A & $\mathrm{B}$ & $\mathrm{C}$ & $\mathrm{D}$ & A & $\mathrm{B}$ & $\mathrm{C}$ & $\mathrm{D}$ & A & $\mathrm{B}$ & $\mathrm{C}$ & $\mathrm{D}$ & & A & $\mathrm{B}$ & $\mathrm{C}$ & $\mathrm{D}$ & A & $\mathrm{B}$ & $\mathrm{C}$ & $\mathrm{D}$ & A & $\mathrm{B}$ & $\mathrm{C}$ & $\mathrm{D}$ & & \\
\hline Sub-Family: Eristalinae & & & & & & & & & & & & & & & & & & & & & & & & & & & \\
\hline Eristalinusaeneus (Scopoli) & 6.1 & 10.1 & - & 8.0 & 8.3 & 13.7 & 16.6 & - & 9.0 & 18.2 & 14.3 & 17.8 & 10.2 & 10.8 & 11.3 & - & 13.2 & - & 10.4 & 15.8 & 9.7 & 4.6 & 12.2 & - & 7.4 & 8.0 & 9.6 \\
\hline Eristalinus sp. & 3.8 & - & - & 16.0 & 4.1 & 2.7 & - & - & - & - & 11.4 & - & 3.2 & 5.1 & - & - & 13.2 & 5.0 & 4.2 & 10.5 & - & - & - & 3.8 & 3.7 & 3.2 & 3.1 \\
\hline Eristalis arbustorum (L.) & 3.8 & 2.9 & - & 12.0 & 4.9 & - & 6.7 & - & - & 6.8 & 5.7 & - & 3.6 & 5.8 & 7.04 & 8.0 & - & 3.3 & 4.2 & - & 16.1 & 4.6 & 9.7 & - & 14.8 & 6.1 & 4.4 \\
\hline Eoseristalis cerealis (Fabicius) & 12.1 & 11.9 & 20.0 & - & 12.4 & 13.7 & 13.3 & - & 13.51 & 18.8 & 14.3 & 14.3 & 10.8 & 10.8 & 11.3 & 12.0 & 13.1 & 10.8 & 10.4 & - & 12.9 & 9.2 & 12.2 & 15.4 & 14.8 & $\begin{array}{c}11 . \\
1\end{array}$ & 11.8 \\
\hline Eristalis tenax (Linnaeus) & 18.9 & 14.6 & 20.0 & 12.0 & 16.5 & 10.9 & 16.6 & 12.5 & 13.51 & 18.8 & 11.4 & - & 13.8 & 14.9 & 9.8 & 16.0 & 13.1 & 12.5 & 20.8 & 26.3 & 16.1 & 13.7 & 12.2 & 19.2 & 18.5 & $\begin{array}{c}16 . \\
0\end{array}$ & 14.7 \\
\hline Eristalis interruptus (Poda) & 7.6 & 14.5 & 20.0 & 12.0 & 8.3 & 10.9 & 16.6 & 12.5 & 9.0 & 11.4 & 11.4 & - & 11.2 & 10.8 & 7.1 & 16.0 & 10.5 & 8.3 & 20.8 & - & - & 9.2 & 9.7 & 11.5 & - & 8.7 & 9.8 \\
\hline Eristalis linaeta (Harris) & - & 7.2 & - & - & 4.1 & 5.5 & - & 18.8 & - & - & - & - & 2.9 & 3.6 & 8.4 & - & 10.5 & 2.5 & - & 21.1 & - & 2.7 & - & - & - & 2.7 & 3.0 \\
\hline Eristalis sp. & 2.3 & - & 8.0 & - & 3.3 & - & 6.7 & - & 4.50 & - & 6.8 & - & 2.6 & 3.6 & 2.8 & - & - & 2.5 & - & - & - & 2.7 & - & - & - & 1.0 & 2.3 \\
\hline Palpada sp. & - & - & - & - & 2.5 & 2.7 & - & - & 2.70 & 4.54 & - & 10.7 & 1.9 & 2.9 & - & - & - & 2.5 & 4.2 & - & 9.7 & 3.9 & - & - & - & 2.0 & 2.1 \\
\hline Helophilus trivittatus Weid & 7.8 & 11.69 & - & 12.0 & - & 9.6 & 16.6 & 18.7 & 9.0 & - & 17.1 & - & 8.5 & 7.2 & 8.4 & 16.0 & 13.2 & 8.3 & - & - & - & 7.3 & 14.6 & 11.5 & 7.4 & 8.0 & 7.5 \\
\hline Helophilus sp. & - & - & - & - & 4.1 & 4.1 & - & - & 4.50 & - & - & - & 1.1 & - & 5.6 & 8.0 & - & - & 10.4 & - & - & - & - & - & - & 2.0 & 1.7 \\
\hline Syritta sp. & - & - & - & - & - & - & - & - & 2.70 & - & - & 10.7 & 1.1 & - & - & 8.0 & - & - & - & - & 6.4 & 1.8 & - & - & 7.4 & 2.0 & 0.9 \\
\hline Copestylum sp. & 3.9 & - & - & - & 3.3 & - & - & - & 4.50 & - & - & - & 0.9 & 2.9 & - & - & - & 6.7 & - & - & 9.7 & 4.6 & - & 7.7 & - & 2.6 & 2.5 \\
\hline Sub total & 65.9 & 72.5 & 68.0 & 72.0 & 71.9 & $\begin{array}{c}74 . \\
0\end{array}$ & 93.3 & 62.5 & 73.0 & 77.3 & 94.3 & 53.5 & 72.5 & 78.3 & 71.8 & 84.0 & 86.8 & 62.5 & 85.4 & 73.7 & 80.6 & 64.2 & 70.7 & 69.2 & 74.1 & $\begin{array}{c}73 . \\
4\end{array}$ & 72.7 \\
\hline \multicolumn{28}{|l|}{ Sub-Family: Syrphinae } \\
\hline Episyrphus balteatus (De Geer) & 15.1 & 7.2 & 12.0 & - & 12.4 & 10.9 & 6.7 & 6.3 & 9.0 & 15.9 & - & 14.3 & 9.2 & 7.2 & 11.3 & - & - & 12.5 & - & - & 19.4 & 9.2 & 7.3 & 7.7 & - & 6.2 & 9.2 \\
\hline Eupeodus corolla (Fabricius) & 3.8 & 4.3 & - & 8.0 & 3.3 & - & - & - & - & - & - & 7.1 & 2.2 & - & 7.1 & 8.0 & - & - & - & - & - & 4.6 & 7.3 & 7.7 & - & 3.0 & 2.3 \\
\hline Scaeva pyrastri (Linneaus) & 3.8 & 4.3 & - & 12.0 & - & 5.5 & - & - & 7.20 & - & - & 14.3 & 3.9 & - & - & - & - & 7.5 & - & - & - & 4.6 & 4.9 & - & - & 1.4 & 3.1 \\
\hline $\begin{array}{l}\text { Sphaerophoria bengalensis } \\
\text { Mac. }\end{array}$ & 3.8 & 4.3 & 8.0 & - & 4.9 & 4.1 & - & - & 5.40 & 6.8 & 5.7 & - & 3.5 & 5.1 & 2.8 & - & - & 5.0 & 8.3 & 15.8 & - & 4.6 & - & - & 7.4 & 4.1 & 4.2 \\
\hline Sphaerophoria scripta (L.) & 3.8 & 7.2 & 12.0 & 8.0 & 4.1 & 5.5 & - & 18.7 & 5.40 & - & - & 10.8 & 6.3 & 5.8 & 2.8 & - & 13.2 & 12.5 & 6.3 & 10.5 & - & 9.2 & 9.7 & 15.4 & 18.5 & 8.0 & 6.7 \\
\hline Syrphus sp. & 3.8 & - & - & - & 3.3 & - & - & 12.5 & - & - & - & & 1.6 & 3.6 & 4.2 & 8.0 & - & - & - & - & - & 3.9 & - & - & - & 1.6 & 1.8 \\
\hline Sub total & 34.1 & 27.5 & 32.0 & 28.0 & 28.1 & $\begin{array}{c}26 . \\
0\end{array}$ & 6.7 & 37.5 & 27.0 & 22.7 & 5.7 & 46.5 & 27.5 & 21.7 & 28.2 & 16.0 & 13.2 & 37.5 & 14.6 & 26.3 & 19.4 & 35.8 & 29.3 & 30.8 & 25.9 & $\begin{array}{c}26 . \\
6\end{array}$ & 27.3 \\
\hline Total individuals & 132 & 69 & 25 & 25 & 121 & 73 & 30 & 16 & 111 & 44 & 35 & 28 & 709 & 138 & 71 & 25 & 38 & 120 & 48 & 19 & 31 & 109 & 41 & 26 & 27 & 733 & 1402 \\
\hline Total Species & 15 & 12 & 7 & 9 & 16 & 13 & 8 & 7 & 14 & 8 & 9 & 8 & & 15 & 14 & 9 & 8 & 14 & 10 & 6 & 5 & 17 & 10 & 9 & 9 & & 19 \\
\hline
\end{tabular}

A=Apple, B= Pear, C=Plum, D=Peach

Number of samples $=120$ sweeps in each fruit crops of each locations

Sampling method=sweep net method

Sampling time $=15^{\text {th }}$ April to $15^{\text {th }}$ September at weekly interval 


\section{Int.J.Curr.Microbiol.App.Sci (2017) 6(7): 2794-2805}

Table.4 Relative abundance of Syrphid flies in fruit orchards of Kashmir during 2014

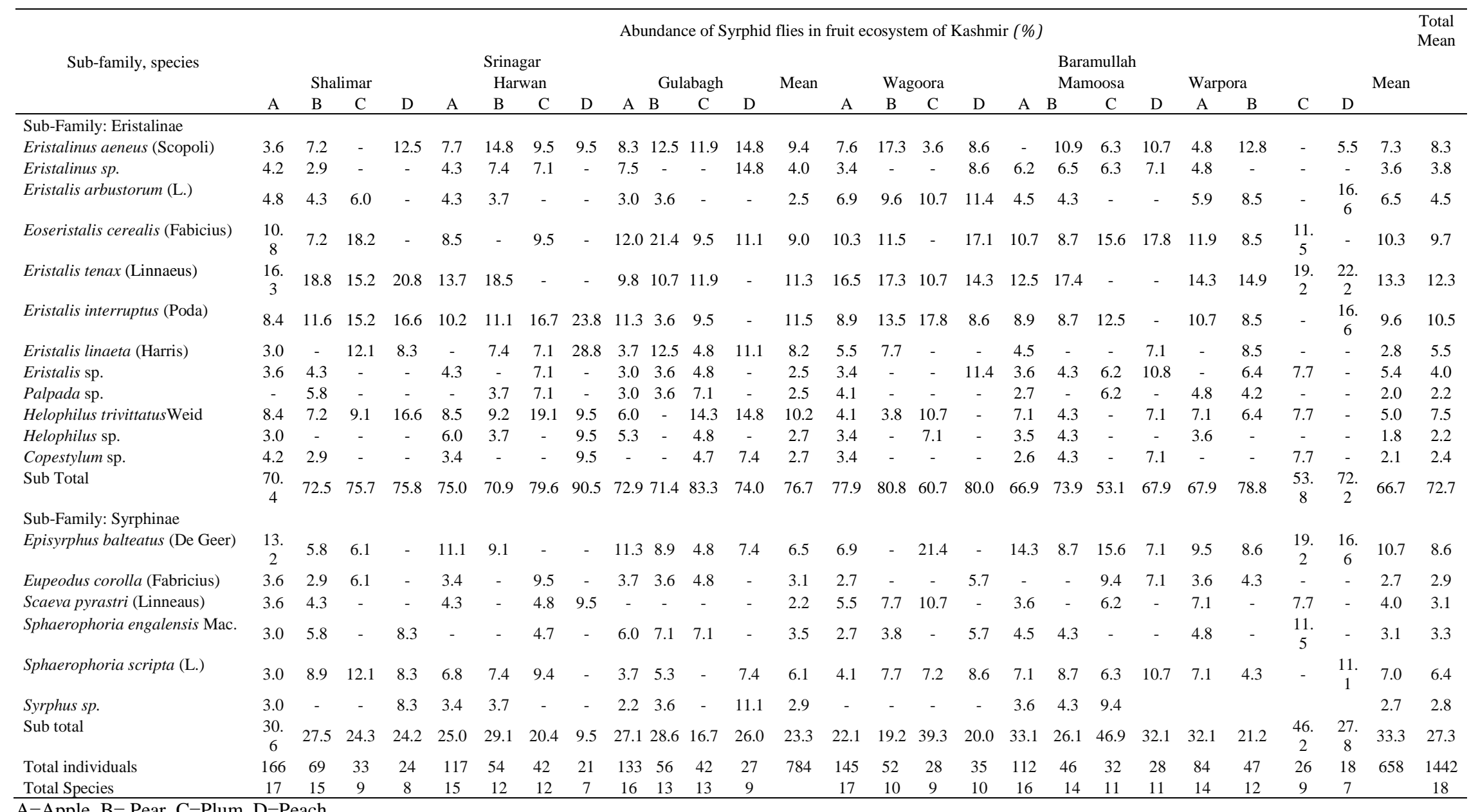

$\mathrm{A}=$ Apple, $\mathrm{B}=$ Pear, $\mathrm{C}=$ Plum, $\mathrm{D}=$ Peach

Number of samples= 120 sweeps in each fruit crops of each locations

Sampling method=sweep net method

Sampling time $=15^{\text {th }}$ April to $15^{\text {th }}$ September at weekly interval 
Table.5 Parameter of abundance of Syrphid flies in fruit ecosystem of Kashmir (2013-2014)

\begin{tabular}{|c|c|c|c|c|c|c|c|c|c|c|c|}
\hline \multirow[t]{2}{*}{ Districts } & \multirow[t]{2}{*}{ Sites } & \multicolumn{2}{|c|}{$S$} & \multicolumn{2}{|c|}{$\mathrm{N}$} & \multicolumn{2}{|c|}{$\begin{array}{l}\text { Diversity } \\
(\mathrm{H})\end{array}$} & \multicolumn{2}{|c|}{$\begin{array}{c}\text { Richness } \\
\text { (Dmg) }\end{array}$} & \multirow{2}{*}{$\begin{array}{c}\text { Mean } \\
\text { Diversity } \\
(\mathrm{H})\end{array}$} & \multirow{2}{*}{$\begin{array}{c}\text { Mean } \\
\text { Richness } \\
\text { (Dmg) }\end{array}$} \\
\hline & & 2013 & 2014 & 2013 & 2014 & 2013 & 2014 & 2013 & 2014 & & \\
\hline \multirow[t]{3}{*}{ Srinagar } & Shalimar & 19 & 18 & 251 & 292 & 2.521 & 2.637 & 3.257 & 2.994 & 2.579 & 3.125 \\
\hline & Harwan & 19 & 18 & 240 & 254 & 3.331 & 2.609 & 3.284 & 3.070 & 2.970 & 3.177 \\
\hline & Gula & 19 & 18 & 218 & 258 & 2.513 & 2.659 & 3.342 & 3.061 & 2.586 & 3.201 \\
\hline \multirow[t]{3}{*}{ Baramullah } & Wagoora & 19 & 18 & 272 & 260 & 2.633 & 2.641 & 3.210 & 3.057 & 2.637 & 3.133 \\
\hline & Mamoosa & 19 & 18 & 218 & 218 & 2.617 & 2.700 & 3.342 & 3.157 & 2.658 & 3.249 \\
\hline & Warpora & 19 & 18 & 203 & 175 & 2.605 & 2.634 & 3.387 & 3.291 & 2.619 & 3.339 \\
\hline
\end{tabular}

$\mathrm{S}=$ Total number of species collected; $\mathrm{N}=$ Total number of individuals in all the species.

$\mathrm{H}=$ Shannon-Wiener biodiversity index; Dmg= Species Richness

Fig.1 The share of species dominant in the Syrphidae community in the temperate fruit orchards of Kashmir during 2013-14

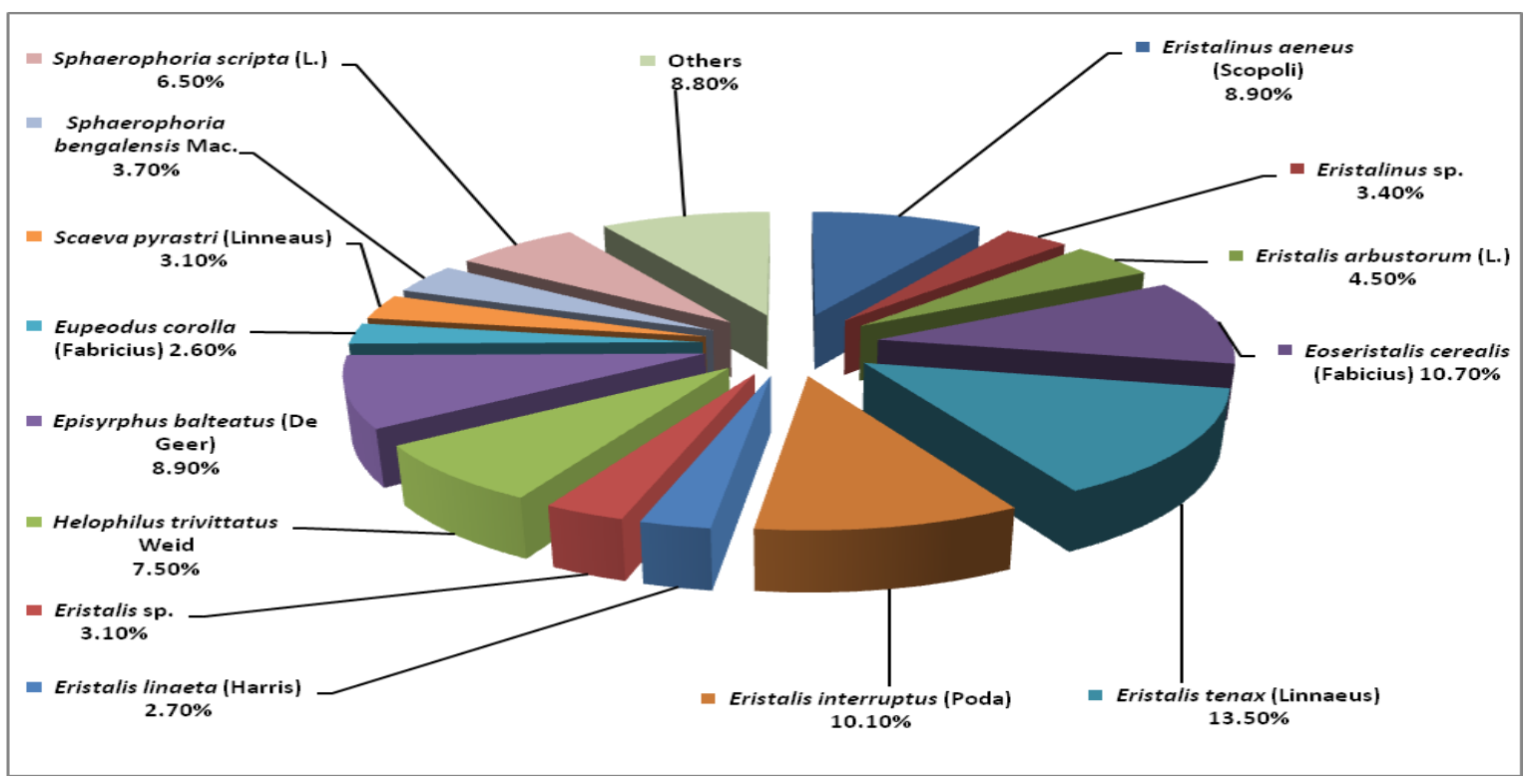

The data depicted that the highest species diversity (3.331) of syrphid flies was recorded in Harwan location of district Srinagar followed by Wagoora location of district Baramullah while as least diversity (2.513) observed at Gulabagh followed by Shalimar (2.521) during 2013. In 2014, the species diversity was highest observed in Mamoosa (2.700) followed by Gulabagh (2.659) and least at Harwan (2.609) followed by Shalimar (2.637) location of district Srinagar. Species richness was highest (3.387) was observed in
Warpora followed by Mamoosa of district Baramullah and least (3.210) of same district in location of Warpora during 2013. In 2014, it was observed least in Shalimar (2.994) followed by Wagoora (3.057) while as highest species richness was observed in Warpora (3.291) followed by Mamoosa (3.157) in fruit orchard of Kashmir.

The mean diversity of syrphid flies were highest (2.970) was observed in Harwan location of district Srinagar while as least diversity was observed in Shalimar (2.579) of 
same district. The mean species richness was observed highest (3.339) in Warpora while as least richness was observed in Warpora location of Baramullah district of fruit orchard of Kashmir. According to Shannonwiener's diversity index ( $\left.H^{\prime}\right)$ the calculated values showed that there is a big difference in the diversity of area which means the syrphidflies are not well scattered in all chosen locations of two districts of Kashmir due to varying topography, type of orchards and availability of aphids (Arif et al., 2014). The yielded values of Margalaf's richness index (Dmg) shown that richness of syrphid flies in the study area is not significantly different except Warpora location.

\section{Acknowledgements}

This research has been funded by University Grant Commision (UGC), New Delhi, India entitled "Biodiversity and utilization of aphidophagous syrphid fly in agro-ecosystem of Kashmir". The author is thankful to UGC for the financial assistance.

\section{References}

Abrol, D.P. 1993. Insect pollination and crop production in Jammu and Kashmir. Curr. Sci., 65(3): 265-269.

Arif, S., M.R. Khan, A. Shehzad, N. Nazir, J. Rahim, F. Naz and Rafi, R. 2014. Biodiversity of syrphid flies (Syrphidae: Diptera) from Poonch District of Azad Kashmir, Pakistan. J. Agri. Technol., 10(6): 1465-1472.

Frank, T. 1999. Density of adult hoverflies (Diptera: Syrphidae) on sown weed strip and adjacent field. J. Appl. Entomol., 123: 351-355.

Shah, G.M., Ulfat Jan and Aijaz, A.W. 2014. A checklist of hoverflies (Diptera: Syrphidae) in the western Himalaya, India. Acta Zoologica Academiae Scientiarum Hungaricae, 60(4), pp. 283-30.
Gilbert, F. 2005. Syrphid aphidophagous predators in a food-web context. European J. Entomol., 102: 325-333.

Haenke, S., B. Scheid, M. Schaefer, T. Tscharntke and Theis, C. 2009. Increasing syrphid fly diversity and density in sown flower strips with in simple and complex landscapes. J. Appl. Ecol., 46: 1106-1114.

Hagvar, E.B. and Nielsen T.R. 2007. The hoverfly fauna (Diptera, Syrphidae) from six years of Malaose trapping in an organic barley field and its boundry in southern Norway. Norwegian. $J$. Entomol., 54: 135-145.

Hopper, J. V., E.H. Nelson, K.M. Daane and Mills N.J. 2011. Growth, development and consumption by four syrphid species associated with the lettuce aphid Nasonovia ribisnigri, in California. Biol. Control, doi:10.106/J.biocontrol. 2011.03.017.

Kevan, P.G. 2002. Flowers, pollination, and the associated diversity of flies. Biodiversity, 3(4): 16-18.

Khan A.A., F.A. Zaki, Z. H. Khan and Mir R.A. 2009. Biodiversity of predacious ladybird beetles (Coleoptera: Coccinellidae) in Kashmir. J. Biol. Control, 23: 43-47.

Khan A.A., R.A. Mir and Zaki F.A. 2007. Relative abundance of predacious ladybird beetles (coleopteran: Coccinellidae) in Kashmir. J. Aphidol., 21(1\&2), 23-30.

Khan, A.A. and Mir, R.A. 2008. Functional response of four predaceous coccinellids Adalia tetraspilota (Hope), Coccinella septempunctata (L.), Calvia punctata (Mulsant) and Hippodamia variegata (Goeze) feeding on the green apple aphid, Aphis pomi De Geer (Homoptera: aphididae). J. Biol. Control, 22: 291-298.

Khan, A.A. 2009. Functional response of Adalia tetraspilota (Hope) (Coleoptera: 
Coccinellidae) on cabbage aphid, Brevicoryne brassicae (L.) (Homoptera: Aphididae). J. Biol. Control 23: 243248.

Khan, A.A., M.A. Shah and Majid S. 2016. Functional response of four syrphid predators associated with green Apple aphid (Hemiptera: Aphididae) in Laboratory. J. Economic Entomol., 109(1): 78-83.

Khan, A.A. 2010. Stage-specific functional response of predaceous ladybird beetle, Harmonia eucharis (Mulsant) (Coleoptera: Coccinellidae) to green apple aphid, Aphis pomi De Geer (Hemiptera: Aphididae). J. Biol. Control, 24: 222-226.

Margalef, R. 1968. Perspectives in Ecological Theory. University of Chicago Press, Chicago, USA.

Mengual, X. and Thompson F. C. 2011. Carmine cochineal killers: the flower fly genus Eosalpingogaster Hull (Diptera: Syrphidae) revised. Systematic Entomol., 36(4): 713-731.

Miranda, G.F.G., A.D. Young, M. M. Locke, S.A. Marshall, J.H. Skevington and Thompson F.C. 2013. Key to the genera of Nearctic Syrphidae. Canadian $J$. Arthropod Identification 23: 1-351.

Mushtaq, T. and Khan, A. A. 2010a. Functional Response of Chrysoperla carnea (Stephens) (Neuroptera: Chrysopidae) to different densities of Aphis craccivora Koch and Aphis pomi De Geer (Homopetera: Aphididae). Indian J. Agri. Sci., 80: 93-95.

Mushtaq, T. and Khan, A.A. $2010 \mathrm{~b}$. Functional and aggregation response of Chrysoperla carnea (Stephens) (Neuroptera: Chrysopidae) to different densities of Bravicoryne brassicae (Homopetera: Aphididae). J. Biol. Control, 24: 28-34.

Naderloo, M and Rad, S.P. 2014. Diversity of hoverfly (Diptera: Syrphidae) communities in different habitat types in Zanjan Province, Iran. ISRN Zool., Volume 2014, Article ID 162343, 5 pages. http:/dx.doi.org/10.1155/162343. Irish wildlife Mannuals, 36:344.

Pape, T. and Evenhuis N. L. 2013. Systema Dipterorum, Version [1.5]. http://www.diptera.org/[Accessed: 8 May 2014].

Development Core Team. 2015. R: A language and environment for statistical computing. R Foundation for Statistical Computing, Vienna, Austria. URL http://www.R-project.org.

Shah, M.A. and Khan, A.A. 2013. Functional response- a function of predator and prey Species. The Bioscan, 8(3): 751758, 2013.

Shah, M.A. and Khan, A.A. 2014. Assessment of coccinellid biodiversity under pesticide pressure in Horticulture ecosystems. Indian J. Entomol., 76(2):107-116.

Shannon, C.E. 1948. A mathematical theory of communication. Bull. Systematic Technol., 27: 379-423.

Ssymank, A., C.A. Kearns, T. Pape and Thompson F.C. 2008. Pollinating flies (Diptera): A major contribution to plant diversity and agricultural production. Biodiversity, 9(1-2):86-89.

Trzcinski, P. and Piekarsha-Bonieca, H. 2013. Dynamics of predatory syrphidae in the apple orchard and neighbouring shrubberies. J. Plant Protection Res., 53(2):119-123.

\section{How to cite this article:}

Akhtar Ali Khan and Shazia Riyaz. 2017. Diversity and Distribution of Syrphid Fly Communities in Temperate Fruit Orchard of Kashmir India. Int.J.Curr.Microbiol.App.Sci. 6(7): 2794-2805. doi: https://doi.org/10.20546/ijcmas.2017.607.390 